\title{
CELLULAR AND SUBCELLULAR COMPART- MENTALIZATION OF STEROID METABOLISM IN THE RAT TESTIS
}

\author{
H. J. VAN DER MOLEN, G. J. VAN DER VUSSE, \\ B. A. COOKE AND F. H. DE JONG \\ Department of Biochemistry (Division of Chemical Endocrinology), \\ Medical Faculty, Erasmus University, Rotterdam, The Netherlands
}

\begin{abstract}
Summary. The following aspects are discussed in relation to the cellular and subcellular localization of steroid metabolism in the rat testis: (1) the localization of enzyme activities for steroid production in interstitial tissue and seminiferous tubules in intact cells and in isolated mitochondrial fractions; (2) steroid production by isolated cellular and subcellular fractions and by the intact testis in vivo; and (3) the effect of cofactors on steroid production by rat testis preparations in vitro. It is concluded that it is difficult to decide whether steroid production and the enzymes involved in steroid metabolism are restricted to specific compartments. Steroid production by the testis can, however, be quantitatively explained by that occurring in the isolated mitochondria of the interstitial tissue.
\end{abstract}

\section{INTRODUCTION}

Increasing interest in the regulation of testis function with respect to steroidogenesis and spermatogenesis has made it obvious that a proper understanding of the intercellular and subcellular localization of the enzymes and steroids involved is required before the biochemical mechanisms involved can be fully appreciated. Ultimately one may hope to explain in molecular terms the obligatory steps required for the apparent effects of LH on testicular steroidogenesis and of those of FSH on the seminiferous tubules which include the process of spermatogenesis. It is said (see Text-fig. 1) that LH will specifically stimulate cyclic AMP (cAMP) and testosterone production in the interstitial tissue, but not in seminiferous tubules (for review, see Rommerts et al., 1974), whereas FSH will only stimulate cAMP production and other processes in the seminiferous tubules (Braun \& Sepsenwol, 1974; Cooke et al., 1974; Dorrington \& Fritz, 1974; Means et al., 1974). This effect of the trophic hormones on cAMP production is thought to be preceded by a specific interaction of LH and FSH with cell-membrane receptors in the two tissues respectively (Dufau et al., 1973; Bhalla \& Reichert, 1974). The binding of LH to the interstitial cells is followed by an increase in steroid production (Rommerts et al., 1974), whilst 


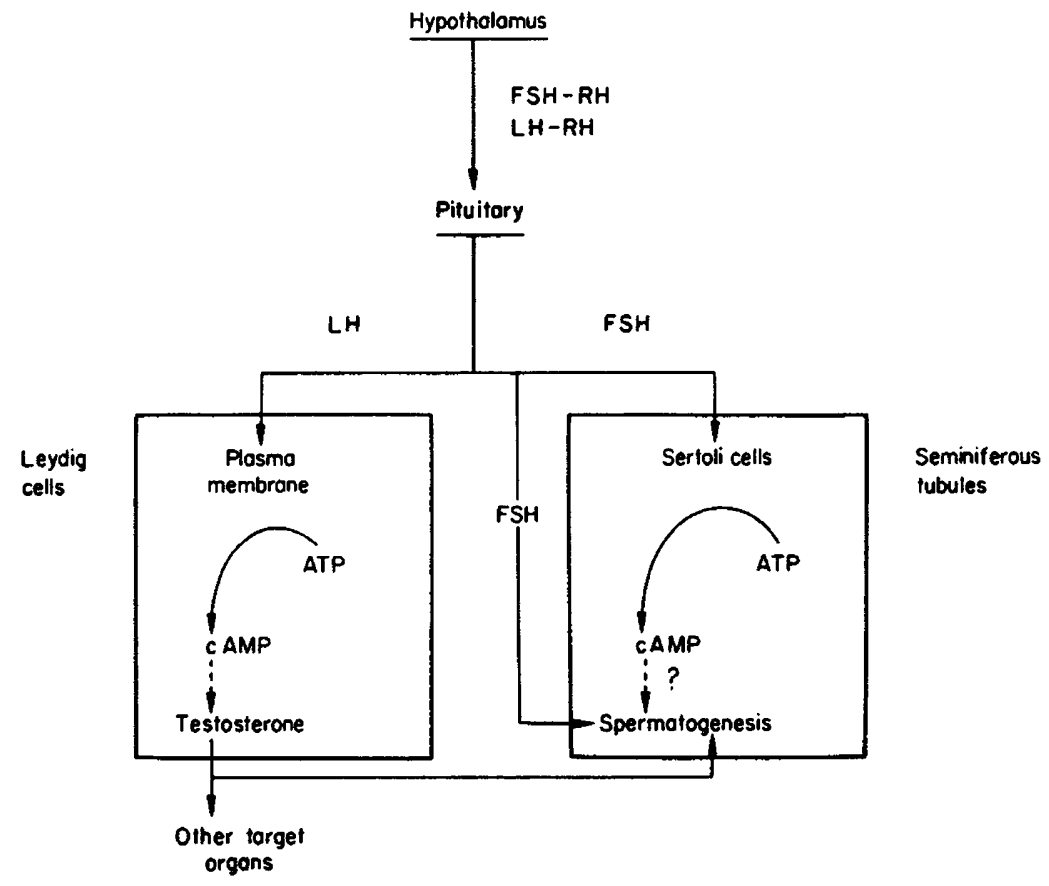

TEXT-Fig. 1. Some relationships between the hypothalamus, pituitary and effects of LH and FSH on testis tissue compartments.

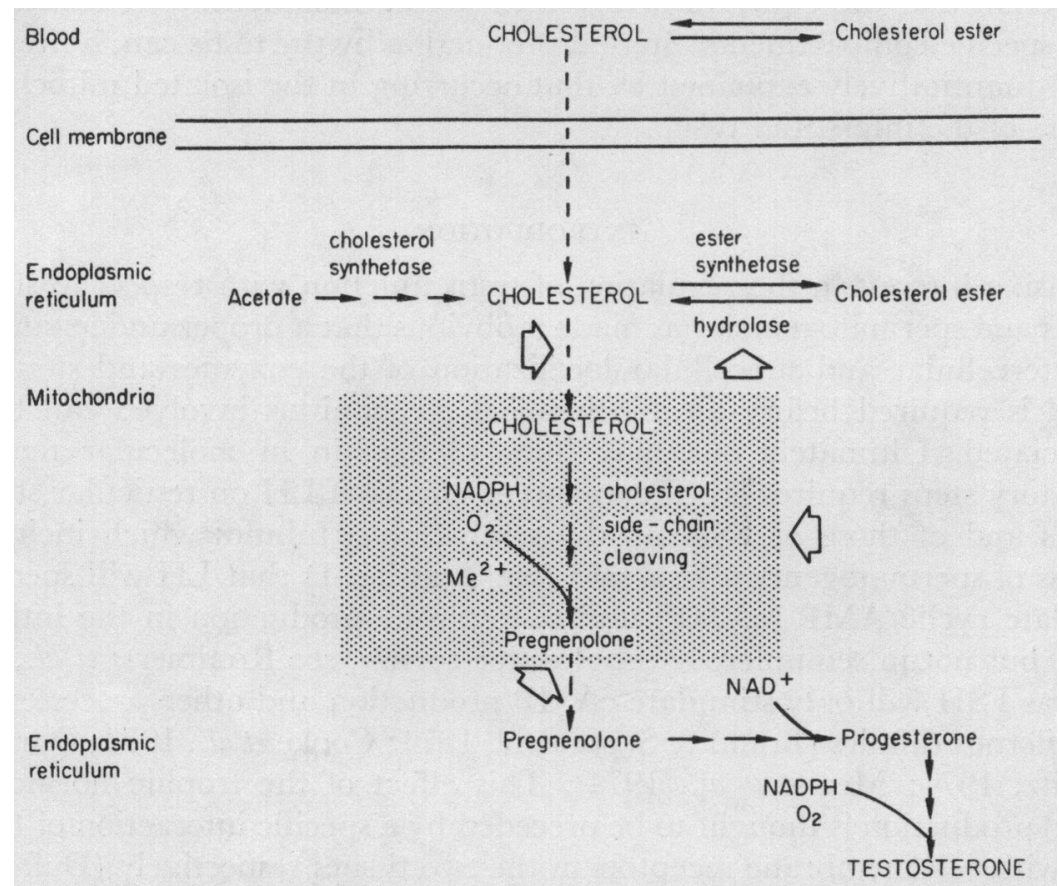

TEXT-Fic. 2. Postulated interrelationships between subcellular compartments and the compounds involved in steroid production in the testicular interstitial tissue and possible loci of actions of LH or HCG (indicated by open arrows). 
FSH brings about the production of an androgen-binding protein in the Sertoli cells (Hansson et al., 1973). It is not clear to what extent other more general effects of trophic stimulation (e.g. on protein kinase and protein synthesis) are required before these specific actions will occur.

Metabolic pathways for testosterone formation are essentially similar for testis, ovary and adrenal, and involve the conversion of mitochondrial cholesterol to testosterone via pregnenolone, progesterone and androstenedione or via pregnenolone and dehydroepiandrosterone.

The available information on the possible molecular effects of LH (or HCG) on steroid production in the interstitial tissue reflects similarities with molecular effects of LH on ovarian steroid production (for review, see Armstrong, 1968) and of ACTH on the adrenal (for review, see Schulster, 1974).

The scheme in Text-fig. 2 includes some of the postulated loci of action of LH on the testis and is mainly derived from information on the adrenal. The postulates include a possible action of LH on: (1) cholesterol ester hydrolysis (Moyle et al., 1973a, b); (2) the rate of transfer of cytoplasmic cholesterol into mitochondria (Ungar et al., 1973); (3) the mitochondrial cholesterol side-chain cleaving activity (Menon et al., 1967). This effect could result from (a combination of) different actions on available cofactors (Robinson \& Stevenson, 1972) or on the association between cholesterol and cytochrome $\mathrm{P}_{450}$ (Mason et al., 1973; Jeffcoate et al., 1974); and (4) the rate of pregnenolone release from the mitochondria which may influence the rate of conversion of cholesterol to pregnenolone as suggested by Koritz \& Hall (1964). Whatever the quantitative effects of trophic hormones on the individual processes shown in Text-figs $l$ and 2 , the ultimate molecular mechanism of $\mathrm{LH}$ should explain the well known increases in testicular testosterone production. In this respect we have studied endogenous steroid production in interstitial tissue mitochondria isolated from normal and HCG-treated rats, and tried to compare the rate of steroid production from these organelles in vitro with the rate achieved by the total testis in vivo.

Several papers have reported the presence of enzyme activities for steroid biosynthesis in seminiferous tubules as well as in interstitial tissue (see Table 1) and the subcellular localization of these enzymes has also been studied (for review, see Tamaoki, 1973). The mere presence of the enzymes for steroid biosynthesis in any tissue compartment does not of course imply that endogenous steroid production really occurs. This will also depend on several other factors, such as the availability of proper precursors, cofactors and the rates of steroid catabolism versus anabolism. Accordingly we have tried to correlate the presence of steroid-metabolizing enzymes in different rat testis tissue preparations with the endogenous steroid production by isolated cellular and subcellular fractions in vitro and by the intact testis in vivo. We have concentrated particularly on the comparison of steroid production in total homogenates and in mitochondrial preparations from interstitial tissue versus similar preparations from seminiferous tubules.

All materials and methods that were used to obtain the results described in the present paper have been presented in detail elsewhere. This includes, for normal and HCG-treated rats, the estimation of endogenous levels of testos- 
Table 1. Presence of enzyme activities for androgen metabolism in the two main compartments of the testis

\begin{tabular}{|c|c|c|c|c|}
\hline Enzyme activity & $\begin{array}{l}\text { Interstitial } \\
\text { tissue }\end{array}$ & $\begin{array}{l}\text { Relative } \\
\text { activity }\end{array}$ & $\begin{array}{l}\text { Seminiferous } \\
\text { tubules }\end{array}$ & References \\
\hline $\begin{array}{l}\text { Cholesterol side-chain } \\
\text { cleaving }\end{array}$ & + & $>$ & $+?$ & $\begin{array}{l}\text { Hall } \text { et al., 1969; Irusta \& } \\
\text { Wassermann, 1971; van der } \\
\text { Vusse } \text { et al., 1973; Bass et al., } 1973\end{array}$ \\
\hline $\begin{array}{l}\Delta^{5} \text {-3 } \beta \text {-Hydroxysteroid } \\
\text { dehydrogenase }\end{array}$ & + & $>>$ & + & $\begin{array}{l}\text { Richards \& Neville, } 1973 \text {; } \\
\text { van der Vusse } \text { et al., } 1974\end{array}$ \\
\hline $17 \alpha$-Hydroxylase & + & $>$ & + & $\begin{array}{l}\text { Hall et al., 1969; Dufau et al., } \\
1971 \text {; Tsang et al., 1973; } \\
\text { Inano, } 1974\end{array}$ \\
\hline C17-C20 lyase & + & $>$ & + & $\begin{array}{l}\text { Dufau et al., } 1971 ; \text { Tsang et al., } \\
\text { 1973; Inano, } 1974\end{array}$ \\
\hline $\begin{array}{l}17 \beta \text {-Hydroxysteroid } \\
\text { dehydrogenase }\end{array}$ & + & $>$ & + & $\begin{array}{l}\text { Dufau et al., 1971; Richards \& } \\
\text { Neville, 1973; Tsang et al., } 1973\end{array}$ \\
\hline$\Delta^{4}, 5 \alpha$-Reductase & + & $\begin{array}{l}>^{*} \\
=\dagger\end{array}$ & + & $\begin{array}{l}\text { Rivarola et al., 1972; Rivarola \& } \\
\text { Podestá, 1973; Folman et al.; } \\
\text { 1973; Dorrington \& Fritz, } 1973\end{array}$ \\
\hline $\begin{array}{l}20 \alpha \text {-Hydroxysteroid } \\
\text { dehydrogenase }\end{array}$ & + & $<$ & + & $\begin{array}{l}\text { Tsang et al., 1973; Inano, 1974; } \\
\text { de Bruijn \& van der Molen, } 1974\end{array}$ \\
\hline
\end{tabular}

* Immature.

$\dagger$ Mature.

terone, pregnenolone and oestradiol in testis tissue preparations (Verjans et al., 1973; Cooke et al., 1972; van der Vusse et al., 1973; de Jong et al., 1973, 1974); the dissection and characterization of isolated interstitial tissue and seminiferous tubules (Rommerts et al., 1973); the isolation of mitochondrial fractions and the production of endogenous steroids by such preparations (van der Vusse $e t$ al., $1973,1975)$; and the subcellular and intracellular distribution 'of $3 \beta$-hydroxysteroid dehydrogenase ( $3 \beta$-HSD) in testis and the effect of HCG on the activity of this enzyme (van der Vusse et al., 1974, 1975).

Table 2. Specific activity of enzyme activities in rat testis tissue preparations

\begin{tabular}{|c|c|c|c|c|}
\hline \multirow[b]{2}{*}{ Enzyme } & \multicolumn{3}{|c|}{ Enzyme activity (nmol/mg protein/min) } & \multirow{2}{*}{$\begin{array}{l}\text { Activity in interstitium } \\
\text { activity in tubules }\end{array}$} \\
\hline & Total testis & $\begin{array}{l}\text { Interstitial } \\
\text { tissue }\end{array}$ & $\begin{array}{l}\text { Seminiferous } \\
\text { tubules }\end{array}$ & \\
\hline $\begin{array}{l}\text { 3 } \beta \text {-Hydroxysteroid } \\
\text { dehydrogenase } \\
\text { pH 7.35 } \\
\text { pH 9.0 }\end{array}$ & $\begin{array}{l}0 \cdot 120 \\
0 \cdot 170\end{array}$ & $\begin{array}{l}1 \cdot 180 \\
1 \cdot 580\end{array}$ & $\begin{array}{l}0.007 \\
0.010\end{array}$ & $\begin{array}{l}168 \\
158\end{array}$ \\
\hline \multirow{3}{*}{$\begin{array}{l}\text { Steroid sulphatase } \\
\text { Carboxyl esterase } \\
\text { Rotenone-insensitive } \\
\text { NADPH-cytochrome c } \\
\text { reductase } \\
\text { Protein }\end{array}$} & 240 & $\begin{array}{c}0.081 \\
1520\end{array}$ & 60 & $\begin{array}{r}6 \cdot 2 \\
25 \cdot 3\end{array}$ \\
\hline & $3 \cdot 0$ & $6 \cdot 9$ & $3 \cdot 3$ & $2 \cdot 1$ \\
\hline & $117 \cdot 4$ & $7 \cdot 1$ & $71 \cdot 2$ & \\
\hline
\end{tabular}

(Data from van der Vusse et al., 1974.) 
Rat testes were separated into seminiferous tubules and interstitial tissue using a wet dissection technique (Rommerts et al., 1973). The relative purity of the isolated tissue fractions was assessed by the relative specific activity of carboxyl esterase (see Table 2 and Text-fig. 6), which is mainly localized in interstitial tissue. From the results in Table 2 , it is evident that the $3 \beta$-HSD may be an even more specific marker for interstitial tissue, because its specific activity here is in the order of $\times 150$ that in the seminiferous tubules, as compared to a factor of $\times 25$ for carboxyl esterase. In order to calculate the relative contribution of enzyme activities in the individual tissue compartments to the total activity in whole testis, it is necessary to correct for the relative amounts of the different tissues in whole testis. As the interstitial tissue accounts for a maximum of $10 \%$ of the whole testis mass, the results in Table 3 would indicate that 95 to $98 \%$ of the total $3 \beta$-HSD activity is localized in the interstitial tissue. From

Table 3. Intercellular distribution of $3 \beta$-dehydrogenase in rat testis tissue

\begin{tabular}{lcc}
\hline \multicolumn{1}{c}{ Tissue } & $\begin{array}{c}\text { Specific activity* } \\
\text { (nmol/mg protein/min) }\end{array}$ & $\begin{array}{c}\text { \% of total } \\
\text { activity }\end{array}$ \\
\hline Total testis & $0.20 \pm 0.06$ & 100 \\
Interstitial tissue $\dagger$ & $1.59 \pm 0.40$ & 95 to 98 \\
Seminiferous tubules & $0.007 \pm 0.004$ & 2 to 5 \\
\hline
\end{tabular}

* Mean values \pm S.D. for four experiments.

$\dagger$ It was assumed that $10 \%$ of testicular protein is of interstitial origin. (Data from van der Vusse et al., 1974.)

such comparisons it is evident that, although $3 \beta$-HSD activity is present in isolated seminiferous tubules, it is only a small part of the total activity in whole testis. It is even difficult to conclude whether such activity in isolated seminiferous tubules reflects endogenous tubular activity or contamination with small amounts of interstitial tissue. This uncertainty can only be resolved if specific marker activities for seminiferous tubules and interstitial tissue would permit calculation of the relative cross contamination of the isolated tissue compartments.

A schematic summary of the localization of some important enzyme activities involved in steroid production is presented in Table 1. This information was derived from studies involving biochemical estimation of enzyme activities in isolated tissue compartments. It is evident that all enzyme activities considered have been demonstrated in isolated interstitial tissue as well as in isolated seminiferous tubules. The specific activities of enzymes involved in testosterone production in interstitial tissue appear to be consistently higher than the

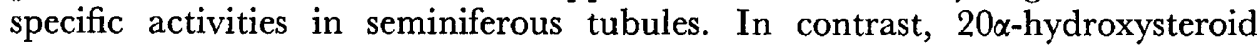
dehydrogenase appears to be higher in tubular tissue than in the interstitium.

In previous studies (Cooke et al., 1972), we concluded that only interstitial tissue produced significant amounts (mean \pm S.D.) of testosterone (an increase of testosterone from $17 \pm 10$ to $56 \pm 15 \mathrm{ng} / 100 \mathrm{mg}$ wet weight (four experiments) 
was observed in isolated interstitial tissue during $180 \mathrm{~min}$ of incubation), whereas seminiferous tubules contained very little testosterone which showed no increase during incubation $(2 \cdot 3 \pm 1.3 \mathrm{ng} / 100 \mathrm{mg}$ seminiferous tubules at zero time versus $1.4 \pm 0.6 \mathrm{ng} / 100 \mathrm{mg}$ at $180 \mathrm{~min}$; four experiments). Results of further studies indicate that the presence of cofactors might considerably influence the production in vitro of testosterone by rat testicular preparations.

Table 4. Production of testosterone by rat testicular tissue preparations

\begin{tabular}{|c|c|c|c|}
\hline \multirow{2}{*}{$\begin{array}{l}\text { Incubation } \\
\text { conditions }\end{array}$} & \multirow{2}{*}{$\begin{array}{l}\text { Incubation } \\
\text { time (min) }\end{array}$} & \multicolumn{2}{|c|}{ Testosterone (ng/mg protein) } \\
\hline & & $\begin{array}{l}\text { Interstitial } \\
\text { tissue }\end{array}$ & $\begin{array}{l}\text { Seminiferous } \\
\text { tubules }\end{array}$ \\
\hline $\begin{array}{l}\text { Whole tissue, } \\
\text { KRBG* }\end{array}$ & $\begin{array}{r}0 \\
180\end{array}$ & $\begin{array}{l}2 \cdot 8 \pm 1 \cdot 4 \quad(4) \\
8 \cdot 3 \pm 3 \cdot 6(4)\end{array}$ & $\begin{array}{l}0.27 \pm 0.09(6) \\
0.38 \pm 0.25(6)\end{array}$ \\
\hline $\begin{array}{l}800 \text { g supernatant, } \\
\text { tris-EDTA } \dagger\end{array}$ & $\begin{array}{r}0 \\
180\end{array}$ & $\begin{array}{r}134 \pm 175(6) \\
1180 \pm 254(6)\end{array}$ & $\begin{array}{l}0.82 \pm 0.57(6) \\
18 \cdot 1 \pm 9.3 \quad(6)\end{array}$ \\
\hline
\end{tabular}

Number of incubations given in parentheses.

* KRBG :Krebs-Ringer buffer $\mathrm{pH} 7 \cdot 4$, containing $0.2 \%$ glucose.

* Tris-EDTA: sucrose buffered with tris at $\mathrm{pH} 7 \cdot 4$, containing sucrose $(0.125 \mathrm{~m})$, EDTA $(0.5 \mathrm{~mm})$, succinate $(20 \mathrm{~mm})$, NADPH (1.0 mM), glucose-6-phosphate $(10 \mathrm{~mm})$, glucose-6-phosphate dehydrogenase $(0.3$ units $), \mathrm{CaCl}_{2}(0.7 \mathrm{~mm}), \mathrm{MgCl}_{2}(5.0 \mathrm{~mm})$, tris- $\mathrm{HCl}$ buffer $(25 \cdot 0 \mathrm{M})$.

The data in Table 4 reflect that the $800 \mathrm{~g}$ supernatant of seminiferous tubules in tris-EDTA buffer containing cofactors may also produce a small amount of testosterone, albeit this production is still very small when compared to the levels and production in interstitial tissue.

\section{SUBCELLULAR LOGALIZATION OF ENZYME AGTIVITIES AND STEROID PRODUGTION}

Subcellular fractions were prepared from whole testis tissue, from isolated interstitial tissue and from isolated seminiferous tubules according to the fractionation scheme in Text-fig. 3. Several enzyme activities and endogenous steroid production were studied in the nuclear fraction, the nuclear free supernatant, the mitochondrial fraction, the microsomal fraction and the $105,000 \mathrm{~g}$ supernatant. The presumed purity of the isolated fractions was derived from the presence of specific markers, which are known to be associated with particular subcellular fractions. From the results in Text-fig. 4, it can be concluded, for example, that the testicular $3 \beta$-HSD activity is mainly localized in the microsomal fraction, because its distribution pattern is comparable with that of well-known microsomal enzymes such as carboxyl esterase and rotenoneinsensitive NADPH-cytochrome c reductase. When the $3 \beta$-HSD activities in mitochondrial and microsomal fractions are corrected for mutual contamination of these fractions on the basis of the presence of carboxyl esterase and cytochrome $c$ oxidase, it can be concluded that mitochondria may contribute to the order of 7 to $15 \%$ of the total $3 \beta$-HSD activity in whole rat testis tissue. 


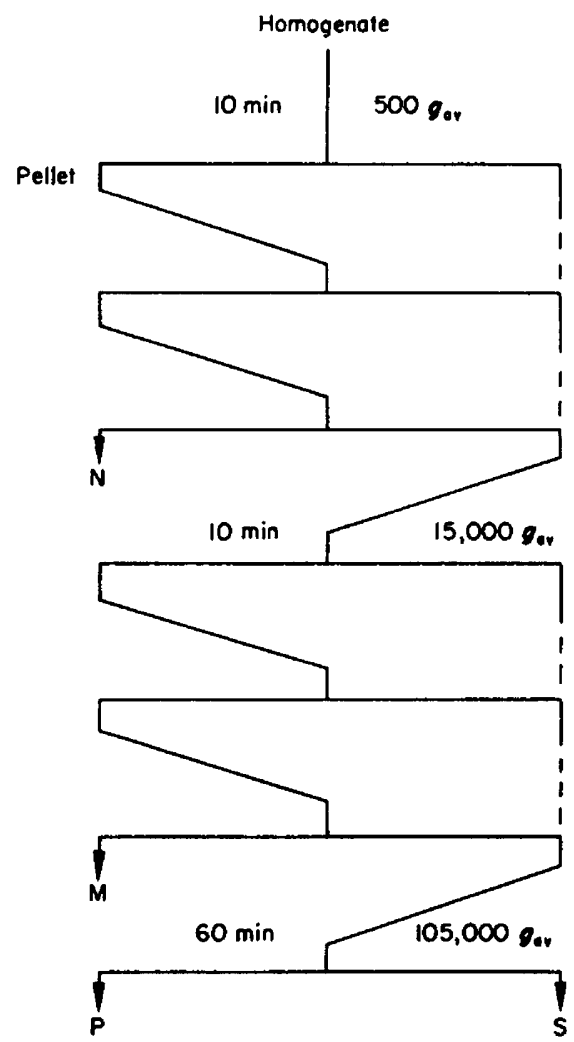

TeXT-FIG. 3. Flow-sheet for the isolation of subcellular fractions from rat testis homogenate. Tissues were homogenized (at $4^{\circ} \mathrm{C}$ in $0.25 \mathrm{M}$-sucrose containing $1 \mathrm{~mm}$-EDTA with an automatic Potter homogenizer (Braun Melsungen, Germany)) three times at $1100 \mathrm{rev} / \mathrm{min}$ for $15 \mathrm{sec}$ each time. Nuclear fractions (N, $500 \mathrm{gav}$ for $10 \mathrm{~min}$, pellet), mitochondrial fractions $(\mathbf{M}, 15,000 \mathrm{gev}$ for $10 \mathrm{~min}$ pellet $)$, microsomal fractions $(\mathbf{P}, 1 \mathrm{hr}, 105,000$ $\boldsymbol{g}_{\mathrm{nv}}$ pellet) and particle-free supernatant (S, $1 \mathrm{hr} 105,000 \mathrm{~g}_{\mathrm{av}}$ supernatant) were obtained by differential centrifugation. The $N$ and $M$ fractions were isolated using a Sorvall $\mathrm{HB}-4$ swing-out rotor in a Sorvall RC 2-B centrifuge and were washed twice with $0.25 \mathrm{M}$-sucrose, containing $1 \mathrm{~mm}$ EDTA. The $P$ and $S$ fractions were obtained with a Beckmann 50 Ti rotor in a Beckmann L2-65B ultracentrifuge. (Data from van der Vusse et al., 1974.)

As all the enzymes required for steroid biosynthesis have been demonstrated in most of the subcellular fractions the endogenous production of steroids by mitochondria was studied in detail. The steroid production in mitochondria can be estimated either as the amount of testosterone formed or, in the presence of cyanoketone, an inhibitor of $3 \beta$-HSD, as the amount of pregnenolone formed. The results in Text-fig. 5 clearly reflect that endogenous steroid production is mainly concentrated in heavy and light mitochondria of whole testis and most, if not all, of this derives from the interstitial cell mitochondria (Text-fig. 6). This is also reflected by the data in Table 5, which indicate that mitochondria from the interstitial tissue of control and HCG-treated rats produce about 100 to 200 times as much steroid/mg protein than do mitochondria from seminiferous tubules. Since the interstitial tissue represents only about $10 \%$ of the testis, its mitochondria would contribute at least 10 to 20 times as much steroid as those from seminiferous tubules to the steroid production of the whole testis. 

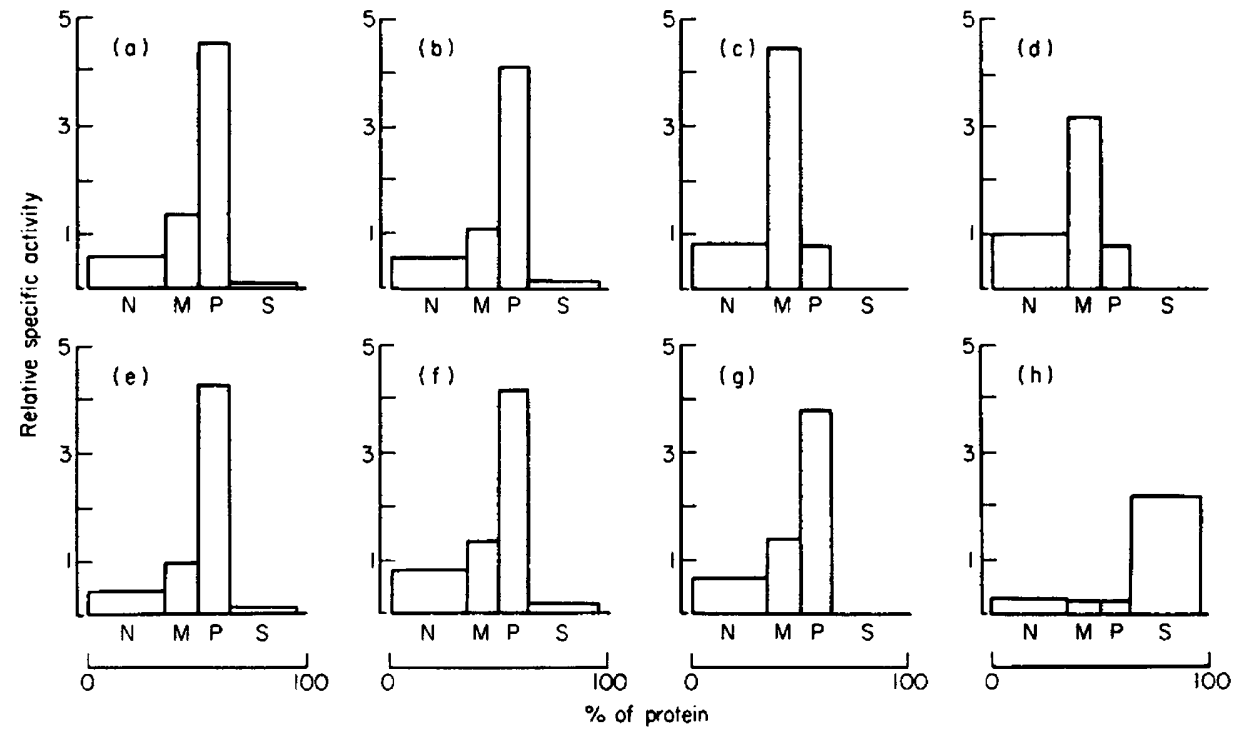

TexT-FIG. 4. Subcellular distribution of $3 \beta$-hydroxysteroid dehydrogenase and marker enzymes in total rat testis tissue. (a) $\Delta^{\mathbf{5}}-3 \beta$-Hydroxysteroid dehydrogenase isomerase, $\mathrm{pH} 7 \cdot 35$; (b) $\Delta^{5}-3 \beta$-hydroxysteroid dehydrogenase isomerase, $\mathrm{pH} 9.0$; (c) cytochrome c oxidase; (d) monoamine oxidase; (e) carboxyl esterase; (f) steroid sulphatase; (g) NADPH-cytochrome c reductase; (h) glucose-6-phosphate dehydrogenase. Relative specific activities (\% of total enzyme activity $\%$ of total protein content) of various fractions- $-\mathrm{N}$, nuclear; $M$, mitochondria; $\mathrm{P}$, microsomal; $\mathrm{S}$, supernatant-are presented as a function of the cumulative values of $\%$ protein in each subcellular fraction. (From van der Vusse et al., 1974.)

It appears from the data in Table 6 that the secretion of testicular testosterone in intact rats is of the same order of magnitude as the production of pregnenolone plus testosterone by mitochondrial fractions obtained from whole testis tissue or from interstitial tissue if the production of such fractions is calculated as a proportion of that of the whole testis.

Table 5. Endogenous steroid production (means \pm S.D.) by mitochondrial fractions of whole rat testis tissue, isolated interstitial cells and seminiferous tubules

\begin{tabular}{|c|c|c|c|c|}
\hline \multirow{3}{*}{$\begin{array}{l}\text { Mitochondrial } \\
\text { fractions }\end{array}$} & \multicolumn{4}{|c|}{ Steroid production* } \\
\hline & \multicolumn{2}{|c|}{ pmol/mg protein/hr } & \multicolumn{2}{|c|}{ nmol/pair of testes/2 hr } \\
\hline & Control & $H C G \dagger$ & Control & $H C G \dagger$ \\
\hline $\begin{array}{l}\text { Whole testis } \\
\text { Interstitial tissue } \\
\text { Seminiferous tubules }\end{array}$ & $\begin{array}{c}580 \pm 165 \\
2662 \pm 1000 \\
18 \pm 15\end{array}$ & $\begin{array}{c}1420 \pm 390 \\
7050 \pm 2850 \\
38 \pm 21\end{array}$ & $\begin{array}{l}32 \pm 9 \\
12 \pm 7 \\
0 \cdot 3 \pm 0 \cdot 2\end{array}$ & $\begin{array}{c}76 \pm 14 \\
42 \pm 14 \\
0 \cdot 6 \pm 0 \cdot 2\end{array}$ \\
\hline
\end{tabular}

(Data from van der Vusse et al., 1975.)

* Steroid production was estimated as the amount of pregnenolone produced during incubations in the presence of cyanoketone.

$\uparrow$ Rats were treated subcutaneously with 100 i.u. HCG/day for 5 days. 

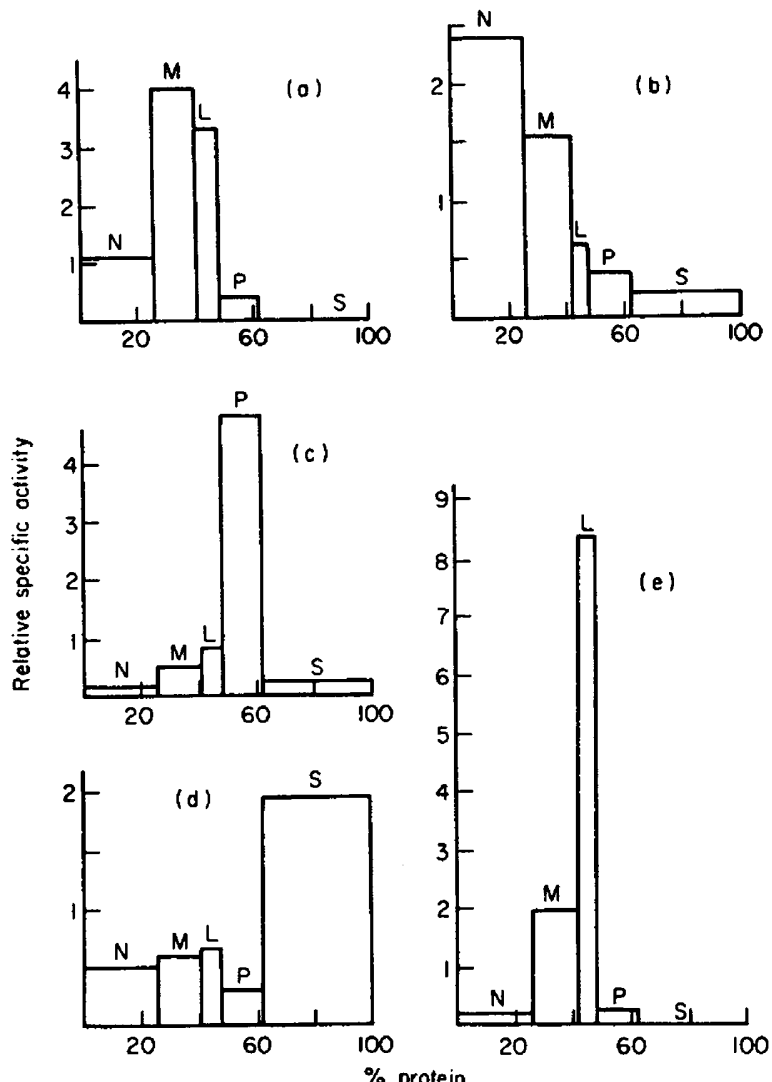

TexT-FIG. 5. Subcellular distribution of steroid production in total rat testis in relation to some markers for subcellular fractions $(\mathrm{N}$, nuclear; $\mathrm{M}$, heavy mitochondria; $\mathrm{L}$, light mitochondria; P, microsomal; S, supernatant). (a) Cytochrome c oxidase; (b) DNA; (c) carboxyl esterase; (d) lactate dehydrogenase; (e) endogenous production of pregnenolone plus testosterone. (From van der Vusse et al., 1973.)

Table 6. Production of steroids by (a) mitochondrial fractions in vitro and (b) secretion of testosterone by rat testes in vivo

\begin{tabular}{rlc}
\hline Experiment & Mitochondrial fraction & $\begin{array}{c}\text { Production of pregnenolone } \\
\text { + testosterone } \\
\text { (nmol/pair of testes/2 hr) }\end{array}$ \\
\hline (a) 1 & Whole testis tissue & $13 \cdot 0$ \\
2 & Whole testis tissue & $10 \cdot 7$ \\
3 & Whole testis tissue & $10 \cdot 3$ \\
4 & Whole testis tissue & $33 \cdot 0$ \\
2 & Interstitial tissue* & $6 \cdot 4$ \\
5 & Interstitial tissue* & $10 \cdot 6$ \\
(b) Secretion of testosterone & 20 \\
(nmol/2 hr/pair of testes) & \\
\hline
\end{tabular}

* Not corrected for loss of tissue during dissection. 


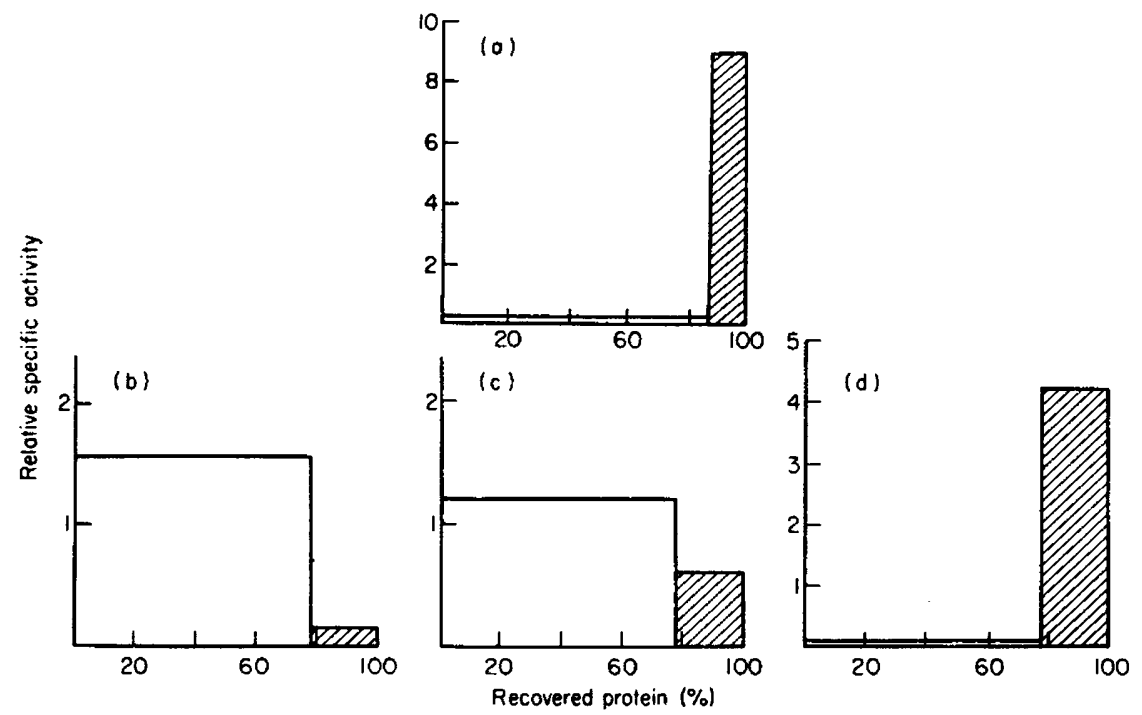

TExT-FIG. 6. Endogenous production of steroids by mitochondria from rat testis interstitial tissue (hatched columns) and seminiferous tubules (open columns) in relation to marker enzymes for characterization of interstitial tissue and seminiferous tubules (a) and for mitochondrial fractions (b, c, d) isolated from these tissue compartments. (a) Whole homogenate, carboxyl esterase; (b) mitochondrial lactate dehydrogenase; (c) mitochondrial cholesterol; (d) mitochondrial production of pregnenolone plus testosterone. (Data from van der Vusse et al., 1973.)

\section{DISCUSSION}

It is well known, that testosterone has some effect on spermatogenesis. Whether this effect requires the presence of the hormone in any of the spermatogenic or other cell types of the seminiferous tubular compartment is completely unknown, but would not appear unlikely. In this respect information on the cellular and subcellular localization of testosterone production in testis tissue may be of importance for future studies concerning specific relationships between steroids and other processes that are required for spermatogenesis. The data presented above, however, do not permit unequivocal conclusions on whether steroid production and the enzyme activities involved (Table 1) are limited solely to specific compartments. On the basis of the presently available knowledge about the association of specific markers with subcellular fractions, one cannot exclude the possibility that small amounts of steroid metabolizing enzyme activities are present in most subcellular fractions, despite a predominance in one in particular. In this respect it appears unwise (Tamaoki, 1973) to summarize the data at hand in terms of exclusive localization in a particular cell organelle. Even the presence of a small amount of enzyme activity may catalyse a particular conversion and thereby permit such a fraction to produce steroids.

It is evident from the results presented that most of the steroid production can be accorded to the interstitial tissue mitochondria. Even if some steroid biosynthesis occurs in the seminiferous tubules it does not necessarily imply a role of such steroids in any tubular function. The presence of an androgenbinding protein in seminiferous tubules, probably in the Sertoli cells (Hansson et al., 1973), and the rapid distribution of injected steroids across the interstitial 
tissue and the seminiferous tubules (Parvinen et al., 1970; Parvinen \& Niemi, 1971) would indicate that sufficient steroid could be bound in the seminiferous tubules even if it were produced only in the interstitial tissue. Therefore, information on the cellular and subcellular localization of steroid production can only serve as the basis for further study on the mechanisms involved in the actions of steroids in the testis.

From the results in Table 5 it is clear that trophic stimulation in vivo is reflected in an increased capacity for steroid production by mitochondrial fractions in vitro. Such information, in combination with the known effects of trophic stimulation on several enzyme activities, should offer a useful model to localize the different processes inside and outside the mitochondria which are involved in their regulation of steroid production in the testis.

\section{ACKNOWLEDGMENT}

The work reported in this paper was supported by a grant from the Dutch Foundation for Medical Research (FUNGO).

\section{REFERENGES}

Armstrong, D.T. (1968) Gonadotropins, ovarian metabolism and steroid biosynthesis. Recent Prog. Horm. Res. 24, 255-308.

BAss, J.J., BELl, J.B.G. \& LACY, D. (1973) Side-chain cleavage of $\left[26-{ }^{14} \mathrm{C}\right]$ cholesterol by rat testicular tissues and their subcellular fractions. F. Endocr. 56, 321-322.

Bhalla, V.K. \& Reichert, L.E. (1974) Properties of follicle-stimulating hormone-receptor interactions. Specific binding of human follicle-stimulating hormone to rat testes. F. biol. C'hem. 249, $43-51$.

Braun, T. \& Sepsenwol, S. (1974) Stimulation of ${ }^{14}$ C-cyclic AMP accumulation by FSH and LH in testis from mature and immature rats. Endocrinology 94, 1028-1033.

Cooke, B.A., DE Jong, F.H., van der Molen, H.J. \& Rommerts, F.F.G. (1972) Endogenous testosterone concentrations in rat testis interstitial tissue and seminiferous tubules. Nature, New Biol. 237, 255-256.

Cooke, B.A., Rommerts, F.F.G., vAN DER KEMP, J.W.C.M. \& VAN DER MOLEN, H.J. (1974) Effects of luteinizing hormone, follicle stimulating hormone, prostaglandin $E_{1}$ and other hormones on adenosine- $3^{\prime}: 5^{\prime}$-cyclic monophosphate and testosterone production in rat testis tissues. Molec. cell. Endocr. 1, 99-111.

de Brutj, H.W.A. \& van Der Molen, H.J. (1974) An assessment of the possible role of $17 \alpha, 20 \alpha-$ dihydroxy-4-pregnen-3-one in the regulation of testosterone biosynthesis by rat and rabbit testis. F. Endocr. 61, 401-410.

DE JONG, F.H., HeY, A.H. \& VAN DER MOLEN, H.J. (1973) Effect of gonadotropins on the secretion of oestradiol-17 $\beta$ and testosterone by the rat testis. F. Endocr. 57, 277-284.

DE Jong, F.H., HeY, A.H. \& VAN DER MoLEN, H.J. (1974) Oestradiol-17 $\beta$ and testosterone in rat testis tissue: effect of gonadotrophins, localization and production in vitro. F. Endocr. 60, 409-419.

Dorrington, J.H. \& FrITz, I.B. (1973) Metabolism of testosterone by preparations from the rat testis. Biochem. biophys. Res. Commun. 54, 1425-1431.

DorRingt on, J.H. \& FrITz, I.B. (1974) Effects of gonadotropins on cyclic AMP production by isolated seminiferous tubules and interstitial cell preparations. Endocrinology 94, 395-403.

Dufau, M.L., DE KRETSER, D.M. \& Hudson, B. (1971) Steroid metabolism by isolated rat seminiferous tubules in tissue culture. Endocrinology 88, 825-832.

Dufau, M.L., Charreau, E.H. \& CatT, K.J. (1973) Characteristics of a soluble gonadotropin receptor from rat testis. F. biol. Chem. 248, 6973-6982.

Folman, Y., Ahmad, N., Sowell, J.G. \& Eik-Nes, K.B. (1973) Formation in vitro of $5 \alpha$-dihydrotestosterone and other $5 \alpha$-reduced metabolites of ${ }^{3} \mathrm{H}$-testosterone by the seminiferous tubules and interstitial tissue from immature and mature rat testis. Endocrinology 92, 41-47.

HALL, P.F., IRBY, C. \& DE KRETSER, D.M. (1969) Conversion of cholesterol to androgens by rat testes: comparison of interstitial cells and seminiferous tubules. Endocrinology 84, 488-496.

Hansson, V., Reusch, E., Trygstad, O., Torgersen, O., Ritzen, E.M. \& French, F.S. (1973) FSH stimulation of testicular androgen binding protein. Nature, New Biol. 246, 56-58.

INano, H. (1974) Studies on enzyme reactions related to steroid biosynthesis. III. Distribution of the 
testicular enzymes related to androgen production between the seminiferous tubules and interstitial tissue. F. Steroid Biochem. 5, 145-149.

Irusta, O. \& WASSERMANN, G.F. (1971) Side-chain cleavage of cholesterol by homogenates of isolated seminiferous tubules of the rat testis. Acta physiol. latinoam. 21, 260-262.

Jeffcoate, G.R., Simpson, E.R. \& Boyd, G.S. (1974) Spectral properties of rat adrenal-mitochondrial cytochrome $\mathrm{P}_{450}$. Eur. J. Biochem. 42, 539-551.

Korurz, S.B. \& Halt, P.F. (1964) End-product inhibition of the conversion of cholesterol to pregnenolone in an adrenal extract. Biochemistry, N.Y. 3, 1298-1304.

Mason, J.I., Estabrook, R.W. \& Purvis, J.L. (1973) Testicular cytochrome-P45o and iron-sulfur protein as related to steroid metabolism. Ann. N.Y. Acad. Sci. 212, 406-419.

Means, A.R., MacDougall, E., Soderling, T.R. \& Corbin, J.D. (1974) Testicular adenosine $3^{\prime}: 5^{\prime}$-monophosphate-dependent protein kinase. Regulation by follicle-stimulating hormone. 7. biol. Chem. 249, 1231-1238.

Menon, K.M., Dorfman, R.I. \& Forchielli, E. (1967) Influence of gonadotrophins on the cholesterol side-chain cleavage reaction by rat-testis mitochondrial preparations. Biochim. biophys. Acta 148 , 486-494.

Moyle, W.R., Jungas, R.L. \& GReep, R.O. (1973a) Influence of luteinizing hormone and adenosine $3^{\prime}: 5^{\prime}$-cyclic monophosphate on the metabolism of free and esterified cholesterol in mouse Leydig-cell tumours. Biochem. 7. 134, 407-413.

Moyle, W.R., Jungas, R.L. \& Greep, R.O. (1973b) Metabolism of free and esterified cholesterol by Leydig-cell tumour mitochondria. Biochem. 7. 134, 415-424.

Parvinen, M. \& Niemi, M. (1971) Distribution and conversion of exogenous cholesterol and sex steroids in the seminiferous tubules and in the interstitial tissue of the rat testis. Steroidologica 2, 129-137.

Parvinen, M., Hurme, P. \& Niemi, M. (1970) Penetration of exogenous testosterone, pregnenolone, progesterone and cholesterol into the seminiferous tubules of the rat. Endocrinology 87, 10821084.

Purvis, J.L., Canick, J.A., Rosenbaum, J.H., Hologgitas, J. \& Latif, S.L. (1973) Control of cytochrome- $\mathrm{P}_{450}$ in rat testis mitochondria by human chorionic gonadotrophin. Archs Biochem. Biophys. 159, 32-38.

Richards, G. \& Neville, A.M. (1973) Metabolism in interstitial tissue and seminiferous tubules of rat. Nature, Lond. 244, 359-361.

Rivarola, M.A. \& Podestá, E.J. (1972) Androgen metabolism of testosterone- ${ }^{14} \mathrm{C}$ by seminiferous tubules of mature rats: formation of $5 \alpha$-androstan- $3 \alpha-17 \beta$-diol- ${ }^{14} \mathrm{C}$. Endocrinology $90,618-623$.

Rivarola, M.A., Podestá, E.J. \& Chemes, H.E. (1973) In vitro testosterone- ${ }^{14} \mathrm{C}$ metabolism by rat seminiferous tubules at different stages of the development: formation of $5 \alpha$-androstandiol at meiosis. Endocrinology 91, 537-542.

Robinson, J. \& Stevenson, P.M. (1972) The energy-linked reduction of NADP + by succinate and its relationship to cholesterol side-chain cleavage. FEBS Letters 23, 327-331.

Rommerts, F.F.G., van Doorn, L.G., GaljaArd, H., Cooke, B.A. \& van der Molen, H.J. (1973) Dissection of wet tissue and of freeze-dried sections in the investigation of seminiferous tubules and interstitial tissue from rat testis. 7. Histochem. Cytochem. 21, 572-579.

Rommerts, F.F.G., Cooke, B.A. \& van der Molen, H.J. (1974) A review. The role of cyclic AMP in the regulation of steroid biosynthesis in testis tissue. F. Steroid Biochem. 5, 279-285.

Schulster, D. (1974) Adrenocorticotrophic hormone and the control of adrenal corticosteroidogenesis. Adv. Steroid Biochem. Pharmacol. 4, 233-295.

TAMAOKI, B. (1973) Steroidogenesis and cell structure, biochemical pursuit of sites of steroid biosynthesis. 7. Steroid Biochem. 4, 89-118.

Tsang, W.N., Collins, P.M. \& LAcy, D. (1973) Steroid metabolism by the seminiferous tubules in vitro and spermatogenesis in the developing rat. $\mathcal{F}$. Reprod. Fert. 34, 513-517.

UNGAR, F., KAN, K.W. \& McCoy, K.E. (1973) Activator and inhibitor factors in cholesterol side-chain cleavage. Ann. N.Y. Acad. Sci. 212, 276-289.

van der Vusse, G.J., Kalkman, M.L. \& van der Molen, H.J. (1973) Endogenous production of steroids by subcellular fractions from total rat testis and from isolated interstitial tissue and seminiferous tubules. Biochim. biophys. Acta 297, 179-185.

van der Vusse, G.J., Kalkman, M.L. \& van der Molen, H.J. (1974) $3 \beta$-Hydroxysteroid dehydrogenase in rat testis tissue. Inter- and subcellular localization and inhibition by cyanoketone and nagarse. Biochim. biophys. Acta 348, 404-414.

van der Vusse, G.J., Kalkman, M.L. \& van der Molen, H.J. (1975) Endogenous steroid production in cellular and subcellular fractions of rat testis after prolonged treatment with gonadotrophins. Biochim. biophys. Acta 380, 473-485.

Verjans, H.L., Cooke, B.A., De Jong, F.H., de Jong, G.M.M. \& van der Molen, H.J. (1973) Evaluation of a radioimmunoassay for testosterone estimation. J. Steroid Biochem. 4, 665-676. 